\title{
Development of a biocompatible nanodelivery system for tuberculosis drugs based on isoniazid-Mg/Al layered double hydroxide
}

This article was published in the following Dove Press journal:

International Journal of Nanomedicine

9 October 2014

Number of times this article has been viewed

\author{
Bullo Saifullah' \\ Palanisamy Arulselvan ${ }^{2}$ \\ Mohamed Ezzat El \\ Zowalaty ${ }^{2,3}$ \\ Sharida Fakurazi ${ }^{2,4}$ \\ Thomas J Webster ${ }^{5,6}$ \\ Benjamin M Geilich ${ }^{5}$ \\ Mohd Zobir Hussein' \\ 'Materials Synthesis and \\ Characterization Laboratory, \\ Institute of Advanced Technology, \\ ${ }^{2}$ Laboratory of Vaccines and \\ Immunotherapeutics, Institute \\ of Bioscience, Universiti Putra \\ Malaysia, Serdang, Selangor, Malaysia; \\ ${ }^{3}$ Department of Environmental \\ Health, Faculty of Public Health and \\ Tropical Medicine, Jazan University, \\ Jazan, Saudi Arabia; ${ }^{4}$ Department of \\ Human Anatomy, Faculty of Medicine \\ and Health Science, Universiti Putra \\ Malaysia, Serdang, Selangor, Malaysia; \\ ${ }^{5}$ Department of Chemical Engineering \\ and Program in Bioengineering, \\ Northeastern University, Boston, \\ MA, USA; ${ }^{6}$ Center of Excellence for \\ Advanced Materials Research, King \\ Abdulaziz University, Jeddah, Saudi \\ Arabia
}

Correspondence: Mohd Zobir Hussein Materials Synthesis and Characterization Laboratory, Institute of Advanced Technology, Universiti Putra Malaysia, Serdang, Selangor 43400, Malaysia

Tel +6038946680 I

Fax +60389435380

Email mzobir@upm.edu.my

\begin{abstract}
The primary challenge in finding a treatment for tuberculosis (TB) is patient non-compliance to treatment due to long treatment duration, high dosing frequency, and adverse effects of anti-TB drugs. This study reports on the development of a nanodelivery system that intercalates the anti-TB drug isoniazid into $\mathrm{Mg} / \mathrm{Al}$ layered double hydroxides (LDHs). Isoniazid was found to be released in a sustained manner from the novel nanodelivery system in humans in simulated phosphate buffer solutions at $\mathrm{pH} 4.8$ and $\mathrm{pH}$ 7.4. The nanodelivery formulation was highly biocompatible compared to free isoniazid against human normal lung and $3 \mathrm{~T} 3$ mouse fibroblast cells. The formulation was active against Mycobacterium tuberculosis and gram-positive bacteria and gram-negative bacteria. Thus results show significant promise for the further study of these nanocomposites for the treatment of TB.
\end{abstract}

Keywords: tuberculosis, isoniazid, $\mathrm{Mg} / \mathrm{Al} \mathrm{LDH}$, nanodelivery system

\section{Introduction}

Mycobacterium tuberculosis (MTB) causes pulmonary tuberculosis (TB) when the bacterium infects the lungs, and extrapulmonary TB where it infects other organs such as the kidneys, liver, spleen, intestine, tonsils, bones, and brain. ${ }^{1}$ Patient noncompliance is the most common challenge in the treatment of TB; this is due to long treatment duration, adverse effects of anti-TB drugs, multidrug prescriptions, and frequent dosing. ${ }^{2} \mathrm{~TB}$ has been a threat to human beings for centuries; the latest global TB report states that there were $\sim 8.6$ million people infected with TB and $\sim 1.3$ million died from the disease in $2012 .{ }^{3}$

Isoniazid (INH) is one of the most powerful anti-TB drugs among four firstline anti-TB drugs; namely rifampin, isoniazid, pyrazinamide, and ethambutol. ${ }^{4}$ Patients are required to take a $300 \mathrm{mg}$ dose of isoniazid daily for 6 months in combination with other anti-TB agents. ${ }^{3}$ However, there are many undesirable side effects associated with isoniazid such as hepatotoxicity, jaundice, hyperacute liver failure, and hydralazine hypotension..$^{4-7}$ Due to these adverse affects, the isoniazid dosage concentration is limited, and when the disease is treated with subtherapeutic doses, it can possibly develop resistance to that particular drug. ${ }^{8}$ Unfortunately, there have been no new anti-TB drugs introduced to the market over the past 5 decades.

Biocompatible drug delivery systems have been the focus of numerous studies since they can improve the efficacy of existing drugs. ${ }^{4}$ For example, drug delivery 
systems can protect drugs from enzymatic and physicochemical degradation and can release the drug at the target site in a sustainable manner. These characteristics can result in a reduction in therapeutic concentrations, frequency of doses, toxicity, and side effects..$^{9,10}$ Different drug delivery systems have been developed for MTB but most are not biocompatible with healthy cells. ${ }^{11-13}$ Specifically, polymerbased delivery systems such as liposomes and solid lipid particles possess certain issues such as poor serum solubility and can cause systemic toxicity with difficulty reaching the target area. ${ }^{11-13}$ Other polymeric systems developed for anti-TB drugs are poly(lactic-co-glycolic acid) systems, but they also cause cytokine release, inflammation, and healthy cellular damage. ${ }^{9,11-14}$

Layered double hydroxides (LDHs) are 2D sheets with a brucite-like layered structure with the general formula $\left[\mathrm{M}^{\mathrm{II}}{ }_{1-\mathrm{x}} \mathrm{M}_{\mathrm{x}}^{\mathrm{III}}(\mathrm{OH})_{2}\right]\left[\mathrm{A}_{\mathrm{x} / \mathrm{n}}{ }^{\mathrm{n}-}\right] \cdot \mathrm{yH}_{2} \mathrm{O}$, where $\mathrm{M}^{2+}$ are divalent metal cations $\left(\mathrm{Mg}^{2+}, \mathrm{Zn}^{2+}\right)$, and $\mathrm{Ni}^{2+}$ and $\mathrm{M}^{3+}$ are trivalent metal cations $\left(\mathrm{Al}^{3+}, \mathrm{Ga}^{3+}, \mathrm{Fe}^{3+}\right.$, or $\left.\mathrm{Mn}^{3+}\right)$, and $\mathrm{A}^{\mathrm{n}-}$ are anions that neutralize the positive charge of the layer. ${ }^{15-18}$ The tendency of LDHs to occupy different anions between their $2 \mathrm{D}$ positive sheets makes them versatile materials that can be applied as improved catalysts, polymerization materials, magnetic materials, flame retardants, and in the removal of toxic materials from the environment. ${ }^{16,19,20}$

Recently, LDHs have emerged as excellent drug delivery systems because of their significant characteristics such as ease of preparation, biocompatibilty, tendency to release intercalated molecules in a sustained manner, and ability to be easily excreted from the body. ${ }^{21-23}$ Different therapeutic agents have been intercalated into LDHs such as cetirizine, L-Dopa, perindopril erbumine, DNA, small interfering (si) RNA, polymers, and dyes. ${ }^{23-26}$ Another formulation was recently developed by intercalating an ultraviolet radiation absorbing agent (cinnammate) into zinc layered hydroxides. ${ }^{27}$ However, its application towards fighting TB has not been well researched.

MTB within macrophages and LDH can be easily targeted to the bacteria since they can easily penetrate macrophages by clathrin-mediated mechanisms. ${ }^{28,29}$ The current study reports the development of a nanodelivery system for the treatment of TB by the intercalation of an anti-TB drug, isoniazid, into the $\mathrm{Mg} / \mathrm{Al} \mathrm{LDH}$. The formulation was found to be biocompatible with human normal lung and 3T3 mouse fibroblast cells. Moreover, it was found to be active against MTB and gram-positive and gram-negative bacteria. As such, this study suggests that the proposed LDH should be further studied for the treatment of TB.

\section{Materials and methods}

All chemicals were of analytical grade and were used without further purification. Isoniazid (99\% pure), magnesium nitrate hexahydrate, and aluminum nitrate nonahydrate were purchased from Sigma-Aldrich (Saint Louis, MO, USA). Deionized water was used in all experiments.

\section{Methods of preparation Isoniazid-Mg/AI LDH nanocomposite via ion exchange method}

INH was intercalated into freshly prepared $\mathrm{Mg} / \mathrm{Al} \mathrm{LDH}$ according to a previously reported method. ${ }^{30}$ In brief, $\mathrm{Mg}\left(\mathrm{NO}_{3}\right)_{2}$ hexhydrated and $\mathrm{Al}\left(\mathrm{NO}_{3}\right)_{3}$ non-hydrated at a 1:2 ratio were dissolved in $250 \mathrm{~mL}$ of deionized water and stirred for 15 minutes while $\mathrm{Mg} / \mathrm{Al} \mathrm{LDH}$ was formed by raising the $\mathrm{pH}$ to 10 by the dropwise addition of a $2 \mathrm{~mol} / \mathrm{L}$ sodium hydroxide aqueous solution. Next, $50 \mathrm{~mL}$ of a $1 \mathrm{~mol} / \mathrm{L}$ solution of isoniazid was added to freshly prepared $\mathrm{Mg} / \mathrm{Al}$ LDH and the sample was stirred for 2 hours. The experiment was conducted under a nitrogen environment. After 2 hours of stirring, the sample was subjected to agitation in an oil bath for 1 day at $70^{\circ} \mathrm{C}$. The next day, the sample was washed three times with deionized water, oven dried at $70^{\circ} \mathrm{C}$ for 2 days, and ground to a powder for further characterization.

\section{INH-Mg/AI LDH nanocomposite}

by co-precipitation method

Isoniazid was intercalated into $\mathrm{Mg} / \mathrm{Al} \mathrm{LDH}$ by a previously reported method. ${ }^{24,30}$ In short, the $\mathrm{Mg}\left(\mathrm{NO}_{3}\right)_{2}$ hexhydrated and $\mathrm{Al}\left(\mathrm{NO}_{3}\right)_{3}$ nonhydrated at a 1:2 ratio were dissolved in $250 \mathrm{~mL}$ of deionized water and stirred for 15 minutes. Next, $50 \mathrm{~mL}$ of a $1 \mathrm{~mol} / \mathrm{L}$ aqueous solution of isoniazid was added. The solution was stirred for an additional 15 minutes and the $\mathrm{pH}$ was raised to 10 by adding a two molar sodium hydroxide solution. After that, the sample was kept on agitation in an oil bath at $70^{\circ} \mathrm{C}$ for 18 hours. Next, the sample was thoroughly washed and kept overnight at $70^{\circ} \mathrm{C}$ to dry for 2 days and subsequently ground into a powder for further characterization.

\section{Material characterization}

A Shimadzu XRD-6000 diffractometer (Shimadzu Corporation, Tokyo, Japan) was used for X-ray diffraction (XRD) analysis. Radiation using $\mathrm{CuK}_{\alpha}$ at $30 \mathrm{KV}$ and $30 \mathrm{~mA}$ was set for recording XRD patterns in the $2 \theta$ range of $2^{\circ}-60^{\circ}$. A Perkin Elmer (Waltham, MA, USA) 100 series Fourier transform infrared (FTIR) spectrophotometer was used for detecting functional groups in the range of $400-4,000 \mathrm{~cm}^{-1}$ by a direct sample method. A LECO model CHNS-932 analyzer 
(Saint Joseph, MI, USA) was used for the analysis of carbon, hydrogen, nitrogen, and sulfur. The thermal stability of the samples was evaluated with a Mettler Toledo thermogravimetric differential analyzer (Greifensee, Switzerland). The surface morphology of the nanocomposites was analyzed using a JEOL JSM-6,400 field-emission scanning electron microscope (Tokyo, Japan). A Shimadzu 1,650 UV PC-UV/ Vis spectrophotometer (Shimadzu Corporation) was used for controlled drug release analysis, a kinetic study, and percentage loading of the drug. An Optima 2,000 DV inductively coupled plasma optical emission spectrometer (Perkin Elmer) was used for the quantification of metallic elements, namely magnesium and aluminum.

\section{Sustained release study}

For the in vitro release of INH, $\sim 0.3 \mathrm{mg}$ of each nanocomposite was placed in $0.1 \mathrm{~mol} / \mathrm{L}$ phosphate buffer solutions (PBS) of $\mathrm{pH} 7.4$ and 4.8 separately in the UV/Vis spectrophotometer and a $\lambda$ max for INH of $271 \mathrm{~nm}$ was selected.

\section{Mycobacterial antimicrobial susceptibility testing using mycobacterial growth indicator tube}

Drug susceptibility testing (DST) of INH-Mg/Al-LDH nanocomposites was employed using a broth-based method non-radiometric fluorescence-based method of MGIT 960 against MTB (American type culture collection [ATCC, Manassas, VA, USA], 25,618 ${ }^{\mathrm{TM}}$ ), and the minimum inhibitory concentration (MIC) of the nanocomposite was determined. The mycobacterial growth indicator tube (MGIT) with

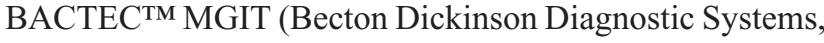
Sparks, MD, USA) 960 growth supplement for DST was used in the MGIT 960 instrument as described previously. ${ }^{31,32}$ All media and reagents were supplied by the manufacturer.

The standard protocol for DST in MGIT 960 was strictly followed as recommended for primary drugs. Culture suspensions for inoculation were well dispersed with no large clumps to avoid false-resistant results. After thorough mixing and homogenization of the suspensions, the tubes were allowed to rest for at least 15 minutes, and the supernatant was used to inoculate the drug-containing media and controls according to manufacturer instructions for DST of first-line drugs. All inoculated drugs containing MGIT 960 tubes were placed in the DST set carrier and were entered into the MGIT 960 instrument as "unknown drugs" using the DST entry feature. The instrument flagged the DST set as "complete" when the control growth reached a growth unit (GU) value of 400 . At that point, the GU values of the tubes were retrieved from the instrument by printing out a DST set report and results were interpreted manually. If the GU of the drug-containing tube was more than 100 when the GU of the growth control was 400 , the results were defined as resistant. If the GU values of the drug-containing tubes were equal to or less than 100 , the results were considered that MTB is susceptible to the drug to be tested. Experiments were repeated with various concentrations of INH Mg/Al LDH nanocomposite suspensions until the MIC was determined.

\section{Non-mycobacterium antimicrobial susceptibility testing}

The synthesized INH-Mg/Al LDH nanocomposites were tested for their antimicrobial activity against gram-positive Staphylococcus aureus and gram-negative Pseudomonas aeruginosa and Escherichia coli bacteria, as well as Candida albicans using the plate colony counting method; the percentage of inhibition was calculated as described previously. ${ }^{33}$ The microorganisms Staphylococcus aureus (ATCC 43300), Pseudomonas aeruginosa (ATCC 27853), Escherichia coli (ATCC 25922), and Candida albicans (ATCC 20408) were purchased from the American Type Culture Collection (ATCC) (Manassas, VA, USA).

\section{Cell culture}

Human normal lung fibroblast MRC-5 and $3 \mathrm{~T} 3$ mouse fibroblast cells were obtained from ATCC. Cells were cultured in Dulbecco's Modified Eagle Medium (DMEM) and Roswell Park Memorial Institute Medium (RPMI) 1,640 media with $10 \%$ fetal bovine serum. Growth media contained 100 units/ $\mathrm{mL}$ penicillin and $50 \mu \mathrm{g} / \mathrm{mL}$ streptomycin. Fibroblast cells were maintained at $37^{\circ} \mathrm{C}$ in a humidified atmosphere of $5 \%$ $\mathrm{CO}_{2}$ in air.

\section{In vitro cell viability assays}

MTT cytotoxicity assays were performed to determine and compare the toxicity of the nanocomposites and INH according to a previously optimized method. ${ }^{34-36}$ In brief, normal human lung fibroblast MRC-5 healthy cells and 3T3 mouse fibroblast cells were procured from ATCC. Cells were cultured in DMEM and RPMI 1,640 media containing 10\% fetal bovine serum and growth medium containing 100 units $/ \mathrm{mL}$ penicillin and $50 \mu \mathrm{g} / \mathrm{mL}$ streptomycin; cells were maintained at $37^{\circ} \mathrm{C}$ in a humidified atmosphere of $5 \% \mathrm{CO}_{2}$. Cells were seeded onto 96 -well culture plates at $1 \times 10^{4}$ cells per well and at post-24 hour seeding, cells were incubated with $100 \mu \mathrm{L}$ medium containing dispersed nanocomposites in various concentrations ranging from $0.781 \mu \mathrm{g} / \mathrm{mL}$ to 
$50 \mu \mathrm{g} / \mathrm{mL}$ without dispersing nanocomposites (as a control) at specific time points of 24,48 , and 72 hours. Following treatment, the amount of formazan crystals formed was measured after 4 hours of exposure to the MTT solution in PBS and absorbance values were measured at $570 \mathrm{~nm}$ by an enzymelinked immunosorbent assay plate reader. Cytotoxicity experiments were performed in triplicate and cytotoxicity results were calculated according to a previously described method; results are presented as mean \pm standard deviation (SD).

\section{Statistical analyses}

Statistical analysis was used to compare the percentage inhibition of INH nanocomposites against different microorganisms using two-way analysis of variance (ANOVA). A Student's $t$-test was used to compare the MICs of INH nanocomposites against MTB. Prism V6.01 statistical software (GraphPad, San Diego, CA, USA) was used for statistical analysis. Statistical significance was defined as $P$-values of $<0.05,<0.01,<0.001$, and $<0.0001$. All data are shown as mean $\pm \mathrm{SD}$.

\section{Results and discussion XRD analysis}

The strongest evidence for the successful intercalation of molecules between interlayer galleries of LDH was increased basal spacing, which was determined by XRD patterns. Figures $1 \mathrm{~A}, 1 \mathrm{~B}$, and $1 \mathrm{C}$ show the XRD patterns of nanocomposite A (isoniazid-Mg/AL-LDH prepared by ion exchange), nanocomposite $\mathrm{B}$ (isoniazid-Mg/ALLDH prepared by co-precipitation methods), and free $\mathrm{INH}$, respectively. $\mathrm{Mg} / \mathrm{Al} \mathrm{LDH}$ with nitrate $\left(\mathrm{NO}_{3}\right)$ as a counter anion had a basal spacing of $8.2 \AA . .^{22,35}$ The XRD pattern of both nanocomposite samples $A$ and $B$ showed that the basal spacing increased to $\sim 12 \AA$. The increase in basal spacing of both nanocomposites $\mathrm{A}$ and $\mathrm{B}$ from 8.2 $\AA$ to $\sim 12 \AA$ is the strongest evidence for the successful intercalation of INH into the interlayer galleries of $\mathrm{Mg} / \mathrm{Al}$ LDH. The average basal spacings were found to be 12.10 $\AA$ and $13.65 \AA$ for nanocomposites A and B, respectively. The second and third reflections of both nanocomposites were slightly broad since they were similar in position for the free drug, indicating adsorption of the drug on the LDH surface. The second reflection for both nanocomposites was also broad, which could possibly be due to the merging of the smaller peaks at $2 \theta=11^{\circ}$ due to intercalation of some carbonate ions, a common phenomenon difficult to avoid. The presence of carbonate ions from carbon, hydrogen, and nitrogen analyses was discussed elsewhere. ${ }^{16,37}$

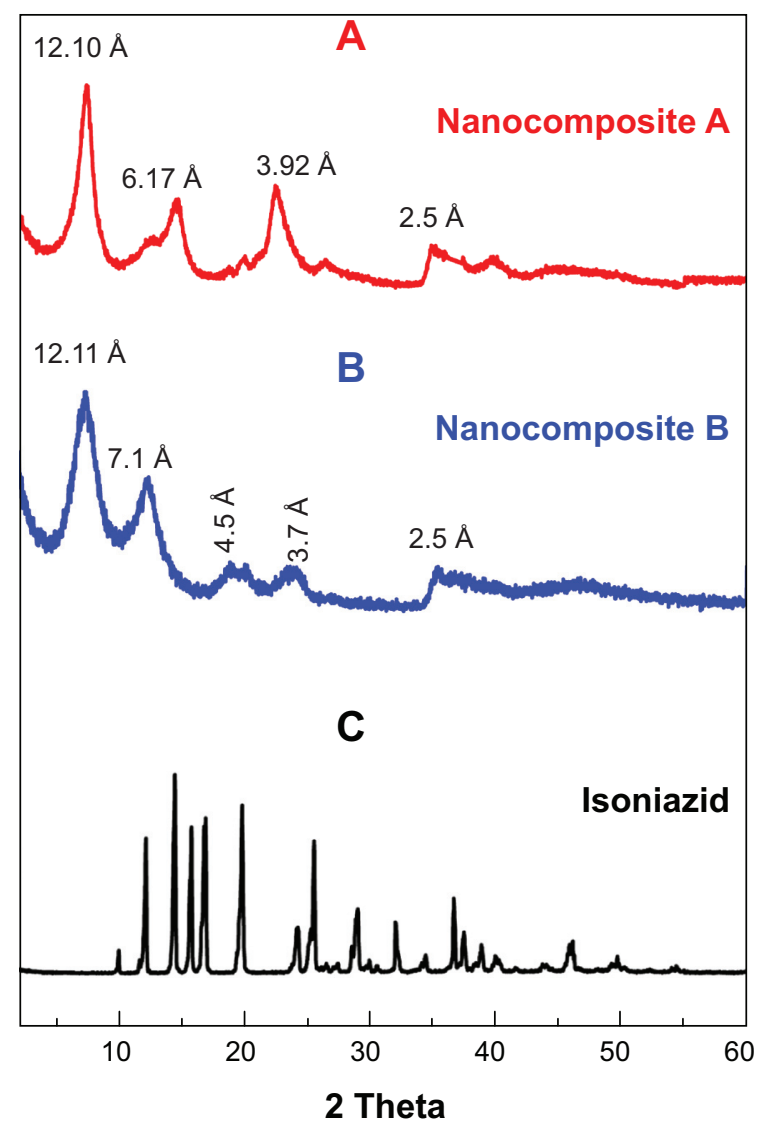

Figure I Powder X-ray diffraction patterns of nanocomposites $A$ and $B$, and free drug isoniazid.

Notes: Nanocomposite (A), isoniazid-Mg/AL-LDH prepared by ion exchange, nanocomposite $(\mathbf{B})$ isoniazid-Mg/AL-LDH prepared by co-precipitation methods, and free isoniazid $(\mathbf{C})$.

Abbreviation: LDH, layered double hydroxide.

\section{Spatial orientation of INH into the interlayer gallery of $\mathrm{Mg} / \mathrm{Al} \mathrm{LDH}$}

Figure $2 \mathrm{~A}$ shows the values for the long and short axes and thickness of INH, which were $10.5 \AA, 7.2 \AA$, and $3.1 \AA$, respectively, as reported previously. ${ }^{30}$ The average basal spacing for INH-Mg/Al LDH prepared by the ion exchange method (nanocomposite A) was found to be $12.00 \AA$. By subtracting the LDH layer thickness of $4.8 \AA$ from the average basal spacing of $12.00 \AA$, we obtained $7.2 \AA$, which was exactly equal to the short (horizontal) axis of INH. However, the electrostatic interaction required can not be achieved by horizontal arrangement of INH. Therefore, the vertical orientation of INH, with tilted angle will facilitate the maximum electrostatic interaction between negatively INH and positively charged layers, as shown in Figure 2B.

The average basal spacing for nanocomposite B was 13.65 $\AA$, and by subtracting the LDH layer thickness, the remaining value was $8.85 \AA$. This did not match with the size of any axis of the INH. The fact that the remaining value $8.85 \AA$ was higher than the horizontal axis and smaller than the long axis 

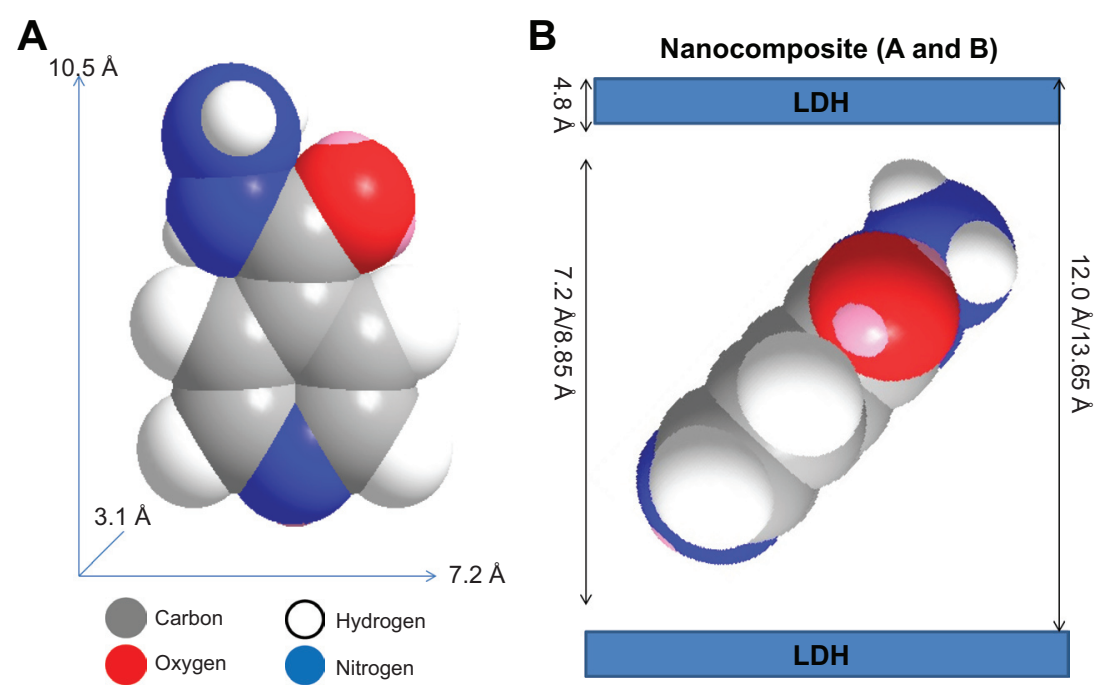

Nanocomposite- $\mathrm{A}=12.0-4.8 \AA=7.2 \AA$

Nanocomposite-B1 $=3.65 \AA=8.85 \AA-4.8 \AA$

Figure 2 Spatial orientation of isoniazid between the interlayer galleries of $\mathrm{Mg} / \mathrm{Al}-\mathrm{LDH}$.

Notes: Molecular size of isoniazid (A), its spatial orientation of isoniazid between the Interlayer galleries of Mg/AI LDHs in nanocomposite A and nanocomposite B (B). Abbreviation: LDHs, layered double hydroxides.

suggests that the INH was intercalated between the layers in the long axis with a slight tilt, as shown in Figure 2C.

\section{FTIR spectroscopy}

FTIR can be very helpful in addition to XRD to indicate the successful intercalation of the molecules into LDH. Figures $3 \mathrm{~A}-\mathrm{C}$ represent the FTIR spectra of INH and nanocomposites A and B. FTIR spectra of the free drug (Figure 3A) show the characteristic $\mathrm{N}-\mathrm{H}$ asymmetric stretching and ring $\mathrm{C}-\mathrm{H}$ asymmetric and symmetric peaks at $3,299 \mathrm{~cm}^{-1}, 3,104 \mathrm{~cm}^{-1}$, and 3,010 $\mathrm{cm}^{-1}$, respectively. ${ }^{38,39} \mathrm{In}$ the FTIR spectra of nanocomposites $\mathrm{A}$ and $\mathrm{B}$, these peaks were overlapped by $\mathrm{O}-\mathrm{H}$ stretching of the $\mathrm{LDH}$ layers and interlayering $\mathrm{H}_{2} \mathrm{O}$ peak, which extended from 2,600 $\mathrm{cm}^{-1}$ to $3,500 \mathrm{~cm}^{-1} .{ }^{16}$ Most of the other bands for functional groups of pure $\mathrm{INH}$, such as $\mathrm{C}=\mathrm{O}, \mathrm{C}=\mathrm{N}, \mathrm{C}-\mathrm{N}$, and ring $\mathrm{C}-\mathrm{C}$, were present in both nanocomposites but slightly shifted. Details of these bands are shown in Table $1 . .^{38-40}$ The shifts in the positions of these bands can be attributed to electrostatic interactions between INH and LDH. The presence of the INH functional group bands in nanocomposites A and B further confirmed XRD results of the successful intercalation of isoniazid into the inorganic LDH.

\section{Elemental analysis}

The presence of organic and inorganic elements was determined by elemental analysis (carbon, hydrogen, nitrogen and sulfur [CHNS] and inductively coupled plasma [ICP]) and used as supporting evidence for the XRD results of successful intercalation. The carbon to nitrogen ratio for nanocomposites $\mathrm{A}$ and $\mathrm{B}$ was higher than the pure drug INH, which could be due to the intercalation of minute amounts of carbonate ions. The presence of carbonate was responsible for the broadening of the second peak in the nanocomposites (peak at $\sim 2 \theta=11^{\circ}$ ). Although the ratio of $\mathrm{Mg}^{2+}$ to $\mathrm{Al}^{3+}$ for the starting material was 2 , it was slightly changed in both nanocomposites $\mathrm{A}$ and $\mathrm{B}$. In nanocomposite $\mathrm{A}$, the $\mathrm{Mg} / \mathrm{Al}$ ratio was 1.70 compared to 2.66 in nanocomposite $\mathrm{B}$. This difference in $\mathrm{Mg} / \mathrm{Al}$ ratios in both samples could be due to

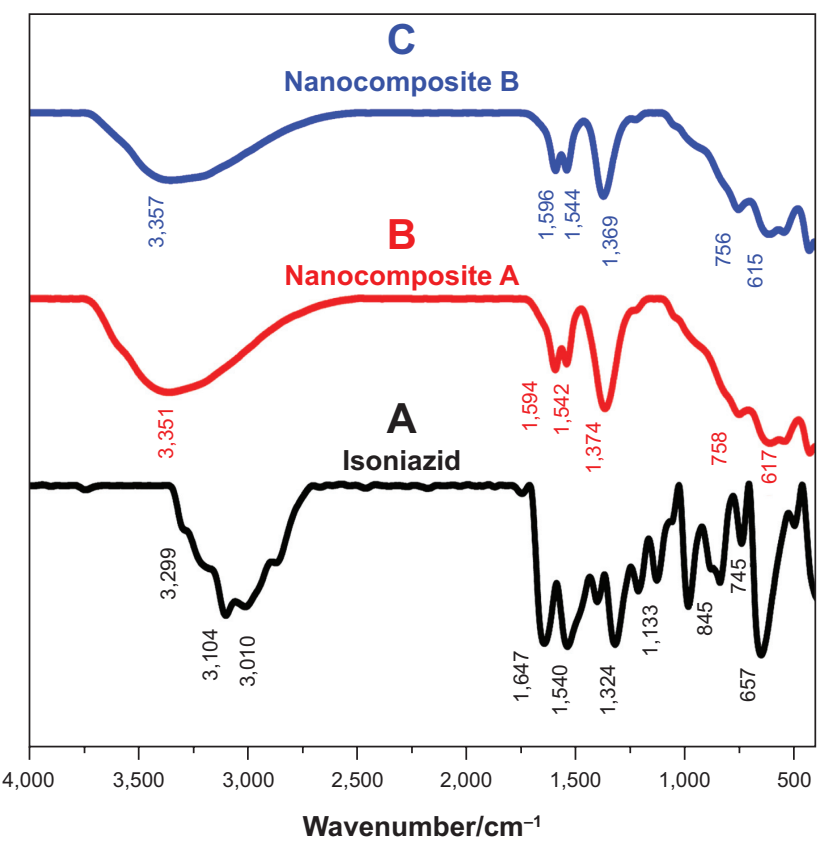

Figure 3 Fourier transform infraredspectrophotometry.

Notes: Fourier transform infraredspectrophotometry of pure isoniazid (A), nanocomposite $\mathbf{A}(\mathbf{B})$, and nanocomposite $B(\mathbf{C})$. 
Table I Vibrational wavenumbers of functional groups of pure INH and its nanocomposites

\begin{tabular}{|c|c|c|c|}
\hline \multirow[t]{3}{*}{ Assignment } & \multicolumn{3}{|c|}{ Vibrational wavenumbers $\mathrm{cm}^{-1}$} \\
\hline & (A) & (B) & (C) \\
\hline & INH & Nanocomposite A & Nanocomposite B \\
\hline $\mathrm{N}-\mathrm{H}$ stretching & $3,299^{38,39}$ & $\begin{array}{l}\text { Overlapped with } \mathrm{OH} \text { of } \mathrm{LDH} \\
\text { and interlayer water }\end{array}$ & $\begin{array}{l}\text { Overlapped with } \mathrm{OH} \text { of } \mathrm{LDH} \\
\text { and interlayer water }\end{array}$ \\
\hline$v(\mathrm{O}-\mathrm{H})$ in the layer; $\mathrm{H}_{2} \mathrm{O}$ & & 3,351 & 3,357 \\
\hline with $\mathrm{OH}$ stretching & & & \\
\hline $\mathrm{C}-\mathrm{H}$ asymstretching & 3,110 & $\begin{array}{l}\text { Overlapped with } \mathrm{OH} \text { of } \mathrm{LDH} \\
\text { and interlayer water }\end{array}$ & $\begin{array}{l}\text { Overlapped with } \mathrm{OH} \text { of } \mathrm{LDH} \\
\text { and interlayer water }\end{array}$ \\
\hline $\mathrm{C}-\mathrm{H}$ symstretching & 3,100 & $\begin{array}{l}\text { Overlapped with } \mathrm{OH} \text { of LDH } \\
\text { and interlayer water }\end{array}$ & $\begin{array}{l}\text { Overlapped with } \mathrm{OH} \text { of } \mathrm{LDH} \\
\text { and interlayer water }\end{array}$ \\
\hline $\mathrm{C}=\mathrm{O}$ & $\mathrm{I}, 647$ & 1,594 & 1,596 \\
\hline $\mathrm{NH}_{2}$ scissoring & $\mathrm{I}, 640^{39}$ & & \\
\hline $\mathrm{C}=\mathrm{N}$ ring & $\mathrm{I}, 546^{37,38}$ & $\mathrm{I}, 543$ & $\mathrm{I}, 544$ \\
\hline $\mathrm{C}-\mathrm{N}$ stretching & $\mathrm{I}, 324^{37,38}$ & $\mathrm{I}, 375$ & 1,369 \\
\hline Ring C-C-C asymbending & 745 & 758 & 756 \\
\hline Ring C-C-C symbending & 657 & 617 & 615 \\
\hline
\end{tabular}

Abbreviations: INH, isoniazid; Asym, asymmetric; Sym, symmetric; LDH, layered double hydroxide; OH, hydroxyl group.

the different preparation methods. The loading was quantified by using nitrogen percentage, which was determined with elemental analysis (CHNS). The loading percentage was found to be $10.34 \%$ in nanocomposite A and $12.25 \%$ in nanocomposite B. Results are summarized in Table 2.

\section{Thermal analysis}

Figures $4 \mathrm{~A}$ and $4 \mathrm{~B}$ show the thermal behavior for nanocomposite A and B, respectively. Three thermal events occurred for both nanocomposites. In nanocomposite $\mathrm{A}$, the first event occurred at $\sim 57^{\circ} \mathrm{C}$ with a $8.71 \%$ mass loss, which can be attributed to the removal of physio bed water. The second event occurred at $\sim 383^{\circ} \mathrm{C}$ with $5.61 \%$ mass loss, and that event can be attributed to the thermal decomposition of INH in nanocomposite A. The free INH thermally decomposed at $\sim 192^{\circ} \mathrm{C}$ with $97 \%$ of mass loss as reported previously. ${ }^{30}$ These results indicate that INH was thermally much more stable between the interlayers Mg/Al LDH. This increased stability can be ascribed to electrostatic interactions between INH and $\mathrm{LDH}$ layers. In nanocomposite A, the third event took place at nearly $466^{\circ} \mathrm{C}$ with $14 \%$ mass loss; this event could be attributed to the dehydroxylation of $\mathrm{Mg} / \mathrm{Al}-\mathrm{LDH}$.

\section{In vitro release of isoniazid}

The in vitro release of INH from nanocomposites was investigated in a human body simulated PBS at pH 4.8 and 7.4 as shown in Figures 5A and 5C. The release of INH from nanocomposite $\mathrm{A}$ in the $\mathrm{PBS}$ solution at $\mathrm{pH} 7.4$ was found to be a two-step process initially faster and then much more sustained for up to 7,000 minutes (Figure 5A). The release at $\mathrm{pH} 4.8$ also showed similar behavior: initially fast then sustained. However, the overall release took $\sim 4,500$ minutes (Figure 5B); the release time at a $\mathrm{pH}$ of 4.8 was shorter than at $\mathrm{pH}$ 7.4. INH release from nanocomposite $\mathrm{B}$ followed a similar trend as nanocomposite $\mathrm{A}$; that is, at two-step release process. The time for release in $\mathrm{pH} 7.4$ and 4.8 was 7,000 minutes and 3,000 minutes, respectively.

In both cases, the release time was shorter at $\mathrm{pH} 4.8$ compared to $\mathrm{pH} 7.4$, which can be explained by the release mechanism. The drug molecules at $\mathrm{pH}$ of 7.4 were released only by an ion exchange mechanism. However, in an acidic medium ( $\mathrm{pH} 4.8$ ), the molecules were released by two phenomena; ion exchange and weathering. Weathering (or degradation) of LDH takes place in an acidic medium as the hydroxyl groups of LDH are protonated and leave the LDH with a much greater stable functional group.

Table 2 Elemental composition of free isoniazid and nanocomposites-A and -B

\begin{tabular}{llllllll}
\hline Sample & $\mathbf{C}$ & $\begin{array}{l}\mathbf{N} \\
(\mathbf{m o l})\end{array}$ & $\begin{array}{l}\mathbf{C} / \mathbf{N} \\
(\mathbf{m o l})\end{array}$ & $\begin{array}{l}\text { Mg } \\
(\mathbf{m o l})\end{array}$ & $\begin{array}{l}\text { Al } \\
(\mathbf{m o l})\end{array}$ & $\begin{array}{l}\text { Molar ratio } \\
\text { Mg/Al }\end{array}$ & $\begin{array}{l}\text { \% INH loading } \\
\text { by N\% }\end{array}$ \\
\hline Isoniazid (INH) & 4.00 & 2.00 & 2.00 & - & - & - & - \\
Nanocomposite A & 1.50 & 0.22 & 6.80 & 1.23 & 0.65 & 2.00 & $10.34 \%$ \\
Nanocomposite B & 1.25 & 0.28 & 4.40 & 1.24 & 0.42 & 3.00 & $12.25 \%$ \\
\hline
\end{tabular}


A

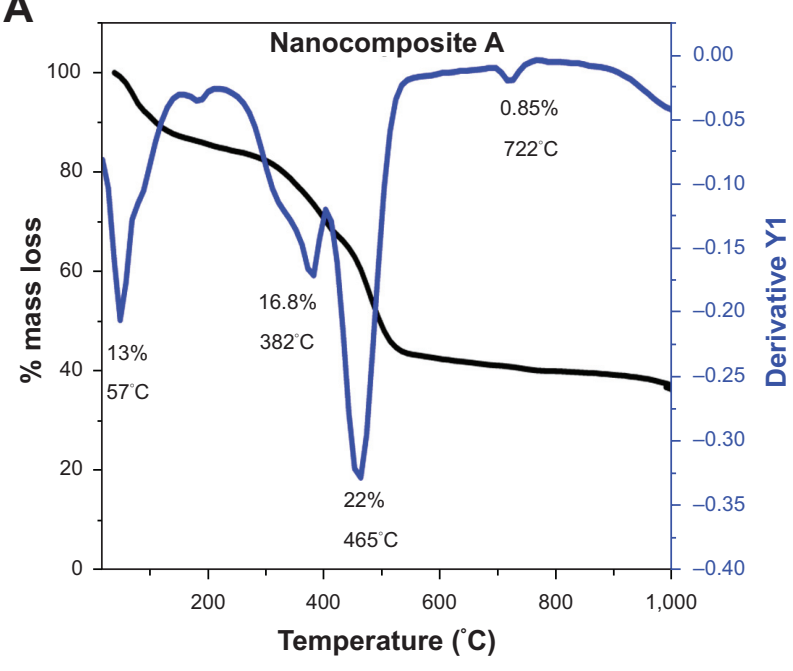

Figure 4 Thermograms for nanocomposites.

Note: Thermograms for nanocomposites A (A) and B (B).

A

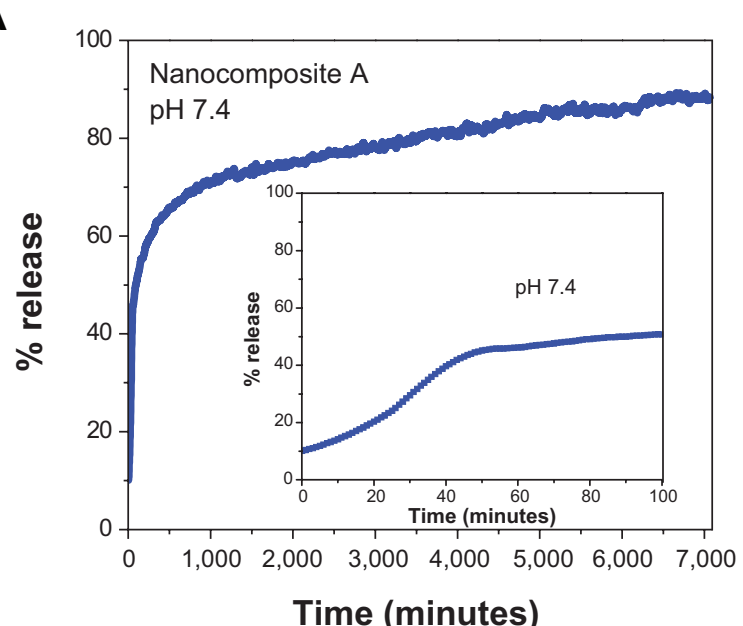

C

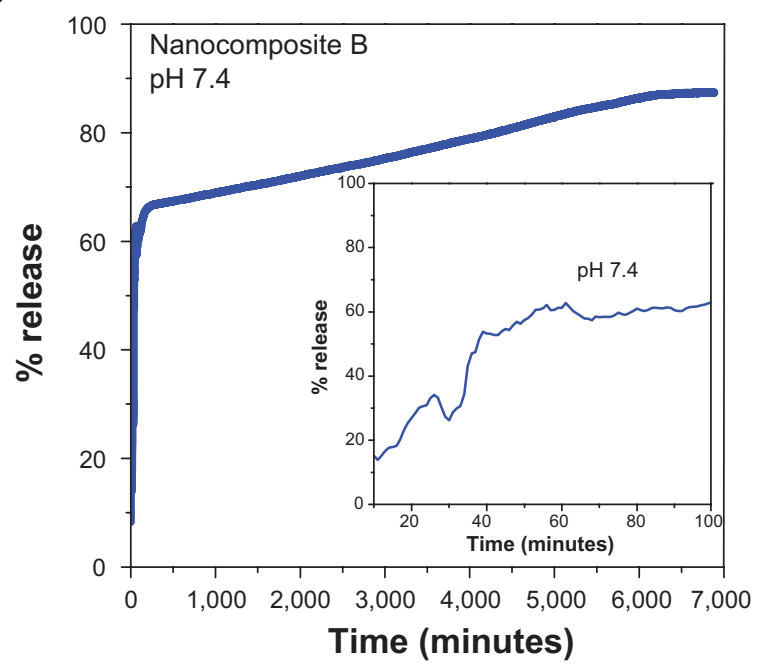

B

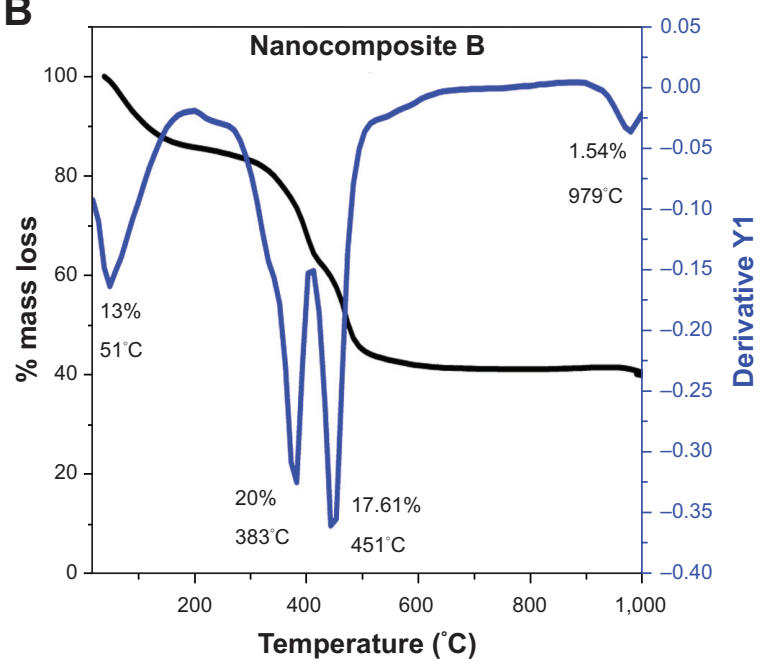

B

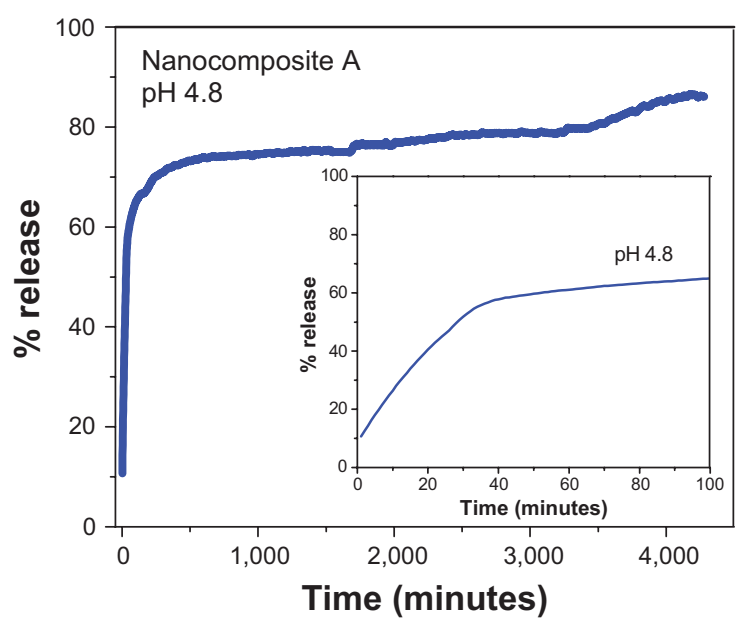

D

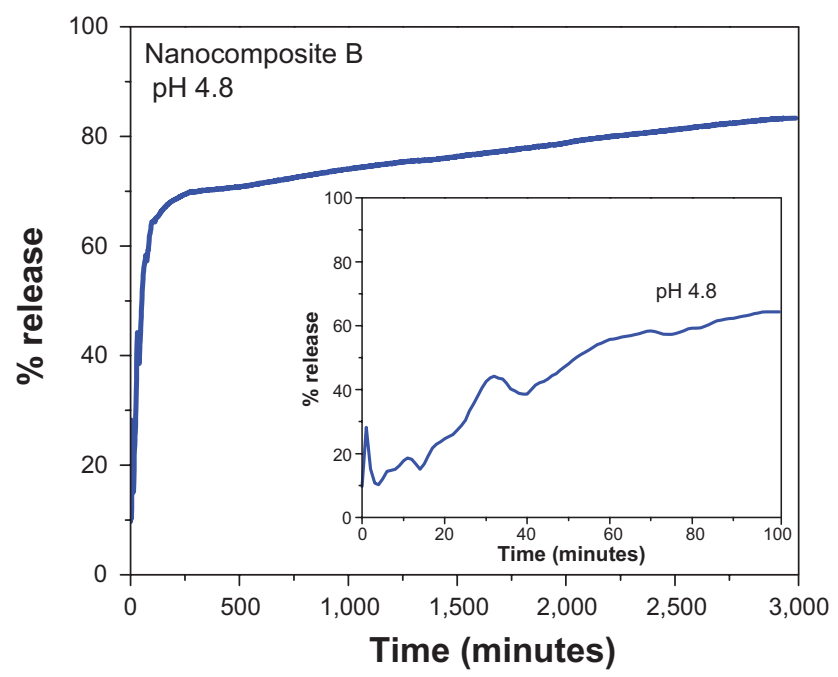

Figure $\mathbf{5}$ In vitro release of isoniazid from nanocomposites $\mathrm{A}$ and $\mathrm{B}$ in different physiological simulated buffers solutions at $\mathrm{pH} 7.4$ and 4.8 .

Notes: $(\mathbf{A})$ and $(\mathbf{B})$ represent the in vitro release of $\mathrm{INH}$ from nanocomposite $\mathrm{A}$ in PBS of $\mathrm{pH} 7.4$ and $\mathrm{pH} 4.8$ respectively. (C) and (D) represents the in vitro release of INH from nanocomposite $\mathrm{B}$ in $\mathrm{PBS}$ of $\mathrm{pH} 7.4$ and $\mathrm{pH} 4.8$ respectively. 


\section{Release kinetics of isoniazid}

The kinetics of drug release was determined using three different models: pseudo first order, pseudo second order, and parabolic diffusion. The linear equations for these models are given below.

The equation for pseudo first order is given as. ${ }^{41}$

$$
\ln \left(\mathrm{q}_{\mathrm{e}}-\mathrm{q}_{\mathrm{t}}\right)=\ln \mathrm{q}_{\mathrm{e}}-\mathrm{k}_{1} \mathrm{t}
$$

where $\mathrm{q}_{\mathrm{e}}$ and $\mathrm{q}_{\mathrm{t}}$ stand for the amount released at equilibrium and at any time ( $\mathrm{t}$ ) respectively. $\mathrm{k}_{1}$ stands for the equilibrium constant and is equal to the slope determined by plotting the $\left(\mathrm{q}_{\mathrm{e}}-\mathrm{q}_{\mathrm{t}}\right)$ vs $\mathrm{t}$.

The second order kinetic equation is represented as: ${ }^{42}$

$$
\mathrm{t} / \mathrm{q}_{\mathrm{t}}=1 / \mathrm{k}_{2} \mathrm{q}_{\mathrm{e}}^{2}+\mathrm{t} / \mathrm{q}_{\mathrm{e}}
$$

The parabolic diffusion kinetic equation may be represented as: ${ }^{25}$

$$
\left(1-\mathrm{M}_{\mathrm{t}} / \mathrm{M}_{\mathrm{o}}\right) / \mathrm{t}=\mathrm{k} \mathrm{t}^{-0.5}+\mathrm{b}
$$

where $\mathrm{M}_{\mathrm{o}}$ and $\mathrm{M}_{\mathrm{t}}$ stand for the drug remaining in the nanocomposites at release time 0 and at any time $(\mathrm{t})$, respectively. All models were utilized to determine in vitro release kinetics of INH from the nanocomposites. A pseudo second-order model was found to fit linearly for the release at $\mathrm{pH} 4.8$ and 7.4 for both of nanocomposites, and the correlation coefficient $R^{2}$ for the pseudo second order was found to be higher than the other two models. The value of correlation coefficients $R^{2}$ for all the models and the rate constants for the pseudo second order are given in Table 3 . Kinetic plots for the pseudo second-order fittings for INH release in PBS at $\mathrm{pH} 4.8$ and 7.4 for both nanocomposites are shown in Figure 6.

\section{Surface morphology}

Surface morphology of the samples was studied by field emission scanning electron microscope (FESEM) at very high resolution $(50,000 \times$ to $100,000 \times)$. Figures $7 \mathrm{~A}, 7 \mathrm{~B}, 7 \mathrm{C}$, 7D, 7E, and 7F show the FESEM micrographs of nanocomposites $\mathrm{A}$ and $\mathrm{B}$ as well as $\mathrm{Mg} / \mathrm{Al} \mathrm{LDH}$. The morphology of nanocomposite A was found to be flaky with non-porous agglomerates (Figures 7A and 7B). This morphology was similar to para-amino salicylic acid-Zn/Al LDH as reported previously. ${ }^{35}$ Nanocomposite B showed a honeycomb-like morphology (Figures 7C and 7D), very similar to the morphology of $\mathrm{Fe}_{3} \mathrm{O}_{4}-\mathrm{CuNiAl}-\mathrm{LDH}$, as reported previously. ${ }^{43}$ The morphology of $\mathrm{Mg} / \mathrm{Al} \mathrm{LDH}$ was found to be similar to nanocomposite $\mathrm{A}$ (Figures $7 \mathrm{E}$ and $7 \mathrm{~F}$ ). The difference in morphology of nanocomposites A and B could possibly be due to different methods of preparation.

\section{Antimycobacterium and antimicrobial assays}

The minimum inhibitory concentration of the as-synthesized INH-Mg/Al-LDH nanocomposites against MTB was found to be $3.6 \mu \mathrm{g} / \mathrm{mL}$ compared to $2.3 \mu \mathrm{g} / \mathrm{mL}$ of the free drug INH (Figure 8), which confirmed the anti-TB activity of the synthesized nanocomposites. The amount of INH present in $3.6 \mu \mathrm{g}$ of nanocomposites $\mathrm{A}$ and $\mathrm{B}$ was calculated from the percentage loading of INH. INH loading was determined from the percentage of nitrogen and was found to be $10.34 \%$ and $12.25 \%$ for nanocomposites $\mathrm{A}$ and $\mathrm{B}$, respectively. The amount of INH present in $3.6 \mu \mathrm{g}$ of nanocomposites $\mathrm{A}$ and $\mathrm{B}$ was found to be $0.37 \mu \mathrm{g}$ and $0.44 \mu \mathrm{g}$, respectively.

The MIC of the free drug (INH, $2.3 \mu \mathrm{g} / \mathrm{mL}$ ) was compared to the effective concentration of INH present in $3.6 \mu \mathrm{g} / \mathrm{mL}$ of nanocomposites $\mathrm{A}$ and $\mathrm{B}$; it was found to be $0.37 \mu \mathrm{g}$ and $0.44 \mu \mathrm{g}$, respectively. The formulations enhanced the therapeutic effect of INH by $\sim 5 \times$ compared to the freeform of INH. The improved efficacy of INH in LDHs can be ascribed to their nanoscaled size and sustained release of INH over longer periods.

We can therefore conclude that the LDH-based

\begin{tabular}{|c|c|c|c|c|c|c|}
\hline \multirow[t]{2}{*}{ Samples } & \multirow[t]{2}{*}{$\mathrm{pH}$} & \multirow[t]{2}{*}{$\%$ release } & \multicolumn{3}{|l|}{$R^{2}$} & \multirow{2}{*}{$\begin{array}{l}\text { Pseudo second } \\
\text { order } \\
\text { Rate constant } \\
\text { K (mg/min) }\end{array}$} \\
\hline & & & $\begin{array}{l}\text { Pseudo } \\
\text { first order }\end{array}$ & $\begin{array}{l}\text { Pseudo } \\
\text { second order }\end{array}$ & $\begin{array}{l}\text { Parabolic diffusion } \\
\text { model }\end{array}$ & \\
\hline Nanocomposite A & 4.80 & 96.00 & 0.72 & 0.99 & 0.62 & $5.31 \times 10^{-5}$ \\
\hline Nanocomposite A & 7.40 & 85.00 & 0.70 & 0.99 & 0.44 & $1.02 \times 10^{-5}$ \\
\hline Nanocomposite B & 4.80 & 90.00 & 0.94 & 0.99 & 0.58 & $7.80 \times 10^{-5}$ \\
\hline Nanocomposite B & 7.40 & 85.00 & 0.76 & 0.99 & 0.85 & $2.81 \times 10^{-5}$ \\
\hline
\end{tabular}
nanodelivery formulations for INH can be very useful in

Table 3 Correlation coefficient and rate constant for in vitro release of isoniazid from Mg/Al-LDHs

Notes: Correlation coefficient $\left(R^{2}\right)$, and rate constants $(\mathrm{K})$ obtained by fitting the data of the release kinetics of isoniazid from nanocomposites $\mathrm{A}$ and $\mathrm{B}$ into phosphate buffered solution at $\mathrm{pH} 4.8$ and 7.4.

Abbreviation: LDHs, layered double hydroxides. 
A

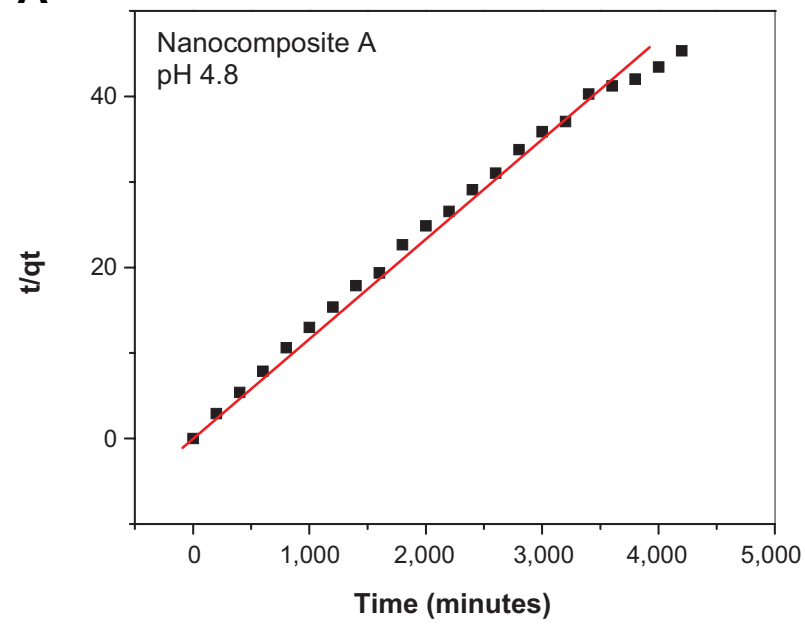

C

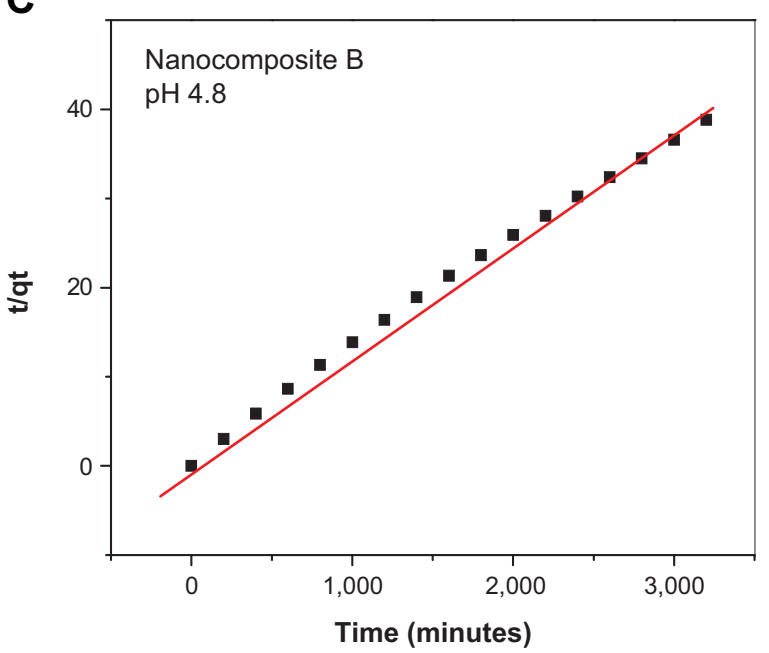

B

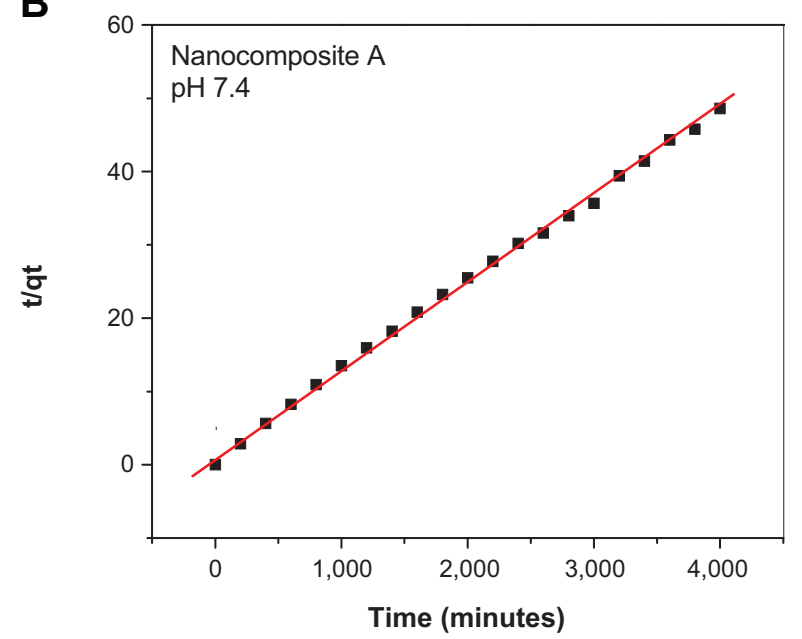

D

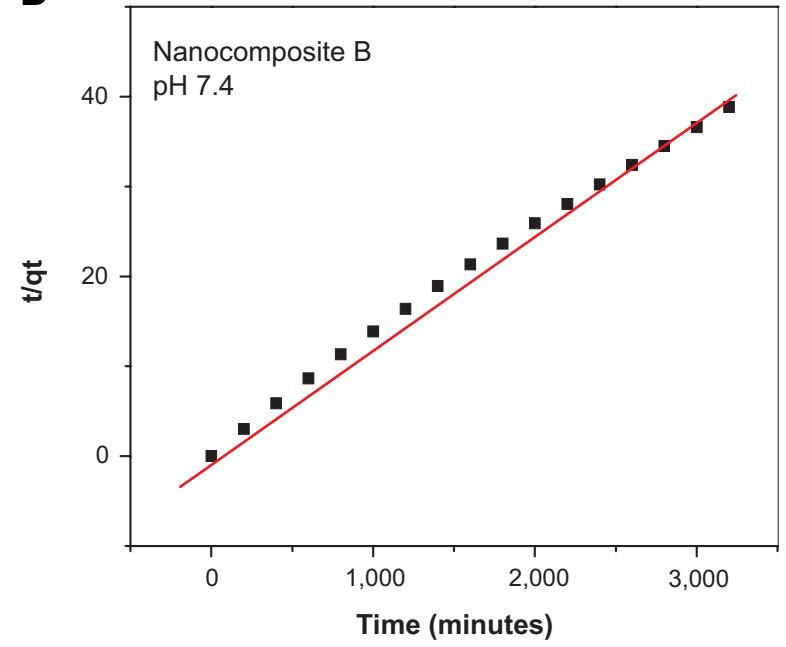

Figure 6 Pseudo second order kinetics of the isoniazid release from nanocomposite $A$ and nanocomposite $B$ in different PBS at pH 4.8 and 7.4 .

Notes: $(\mathbf{A})$ and $(\mathbf{B})$ represent the pseudo second order fitting of isoniazid in vitro release from nanocomposite $\mathrm{A}$ in PBS of pH 4.8 and 7.4 respectively. (C) and (D) represents the pseudo second order fitting of isoniazid in vitro release from nanocomposite B in PBS of pH 4.8 and 7.4.

Abbreviation: PBS, phosphate buffer solution.

coping with the deadly disease of TB and have the potential to decrease the side effects of INH as a step forward in making chemotherapy for TB more patient friendly. Results of antimicrobial testing showed that the nanocomposites had antibacterial activity against gram-positive and gramnegative bacteria and yeast, as shown in Figures 9A and 9B from the percentage inhibition of each compound against different organisms.

\section{Cytotoxicity study against human normal lung cells MRC-5 and 3 T3 mouse fibroblast cells}

Colorimetric assays for testing the biocompatibility of $\mathrm{Mg} / \mathrm{Al}$ $\mathrm{LDH}$ and nanocomposites of isoniazid and $\mathrm{Mg} / \mathrm{Al} \mathrm{LDH}$ were used in this study. Biocompatibility of the samples against human normal lung cells, MRC-5, and 3T3 mouse fibroblast cells was determined. We treated both sets of cell lines with a wide range of sample concentrations $(0.781$ to $50 \mu \mathrm{g} / \mathrm{ml}$ for 24, 48, and 72 hours). The INH-Mg/Al LDH nanocomposites and $\mathrm{Mg} / \mathrm{Al} \mathrm{LDH}$ did not indicate any toxicity to these cell lines. However, free INH was found to be toxic in a time- and concentration-dependent manner against these cells, as previously reported..$^{30} \mathrm{INH}$ was very toxic and the viability of the two cell lines was found to be $<20 \%$ when treated with $50 \mu \mathrm{g} /$ $\mathrm{mL}$ for 72 hours. Viability of human lung and $3 \mathrm{~T} 3$ fibroblast cells was found to be $\sim 85 \%$ when treated with $\mathrm{INH}-\mathrm{Mg} / \mathrm{Al}$ LDH nanocomposites, as shown in Figure 10. Thus, it can be concluded that INH-Mg/Al LDH nanocomposite formulations were almost $3 \times$ more biocompatible compared to free INH. Thus, we conclude that nanocomposite formulations of INH based on $\mathrm{Mg} / \mathrm{Al} \mathrm{LDH}$ are $3 \times$ more biocompatible with these cells compared to free isoniazid. 


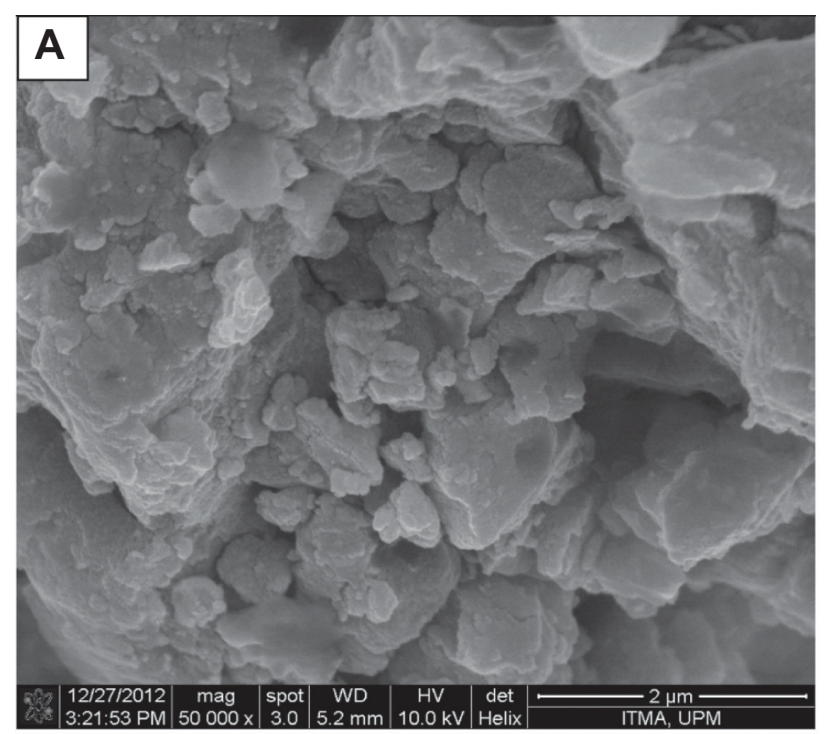

Nanocomposite A

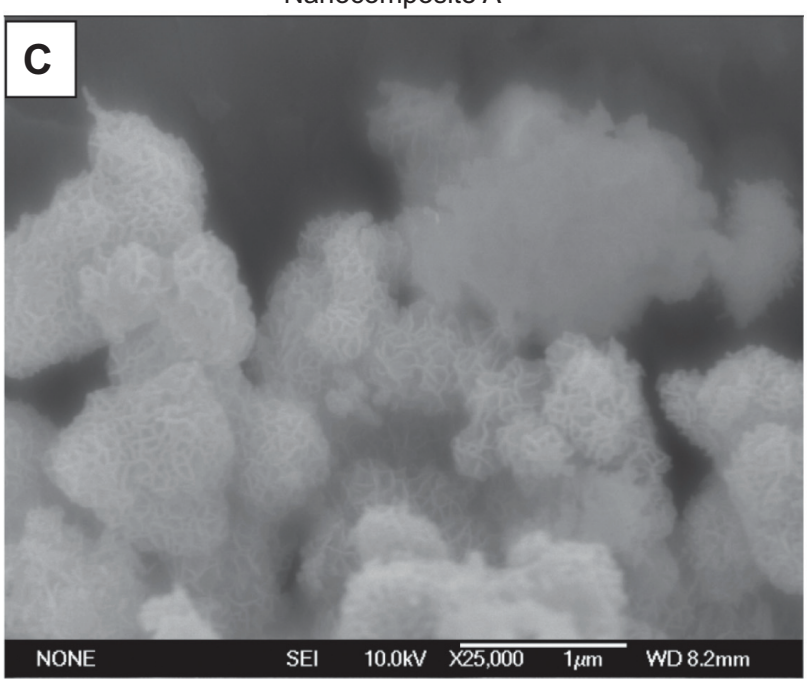

Nanocomposite B

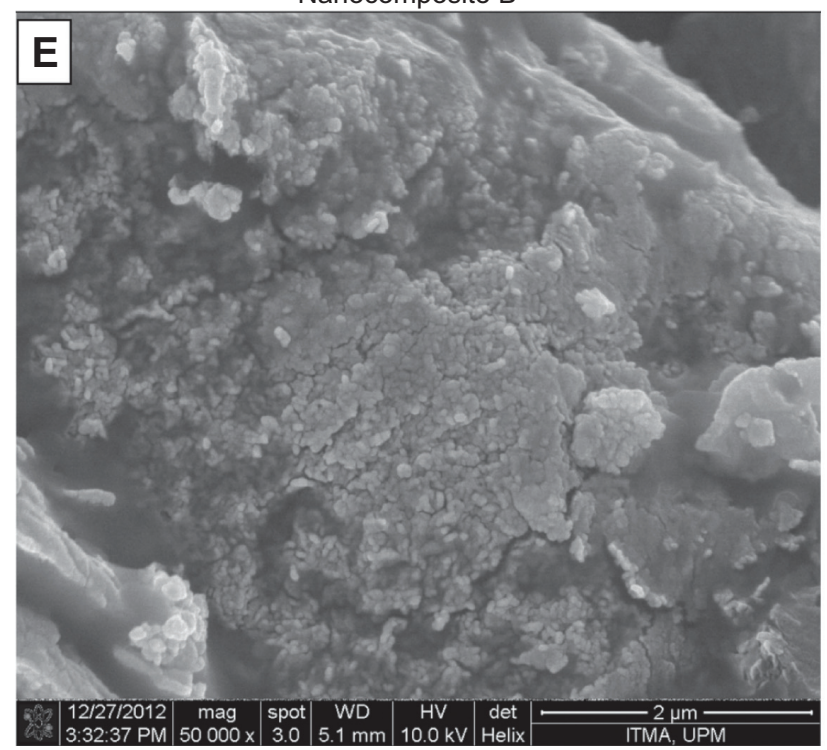

Mg/AI-LDHs

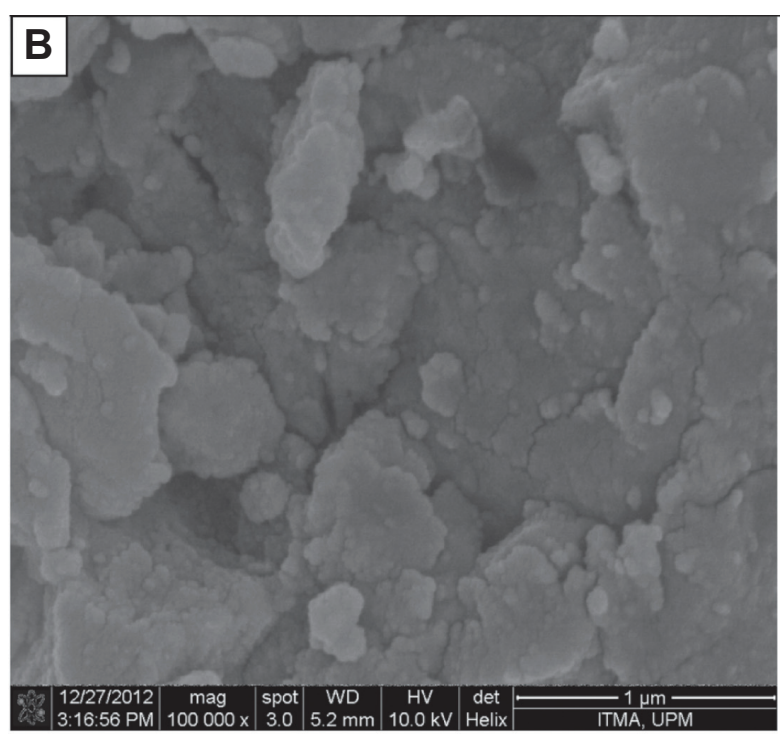

Nanocomposite A

\section{D}

NONE SEI $10.0 \mathrm{kV} \times 150,000 \overline{100 \mathrm{~nm}}$ WD $8.2 \mathrm{~mm}$

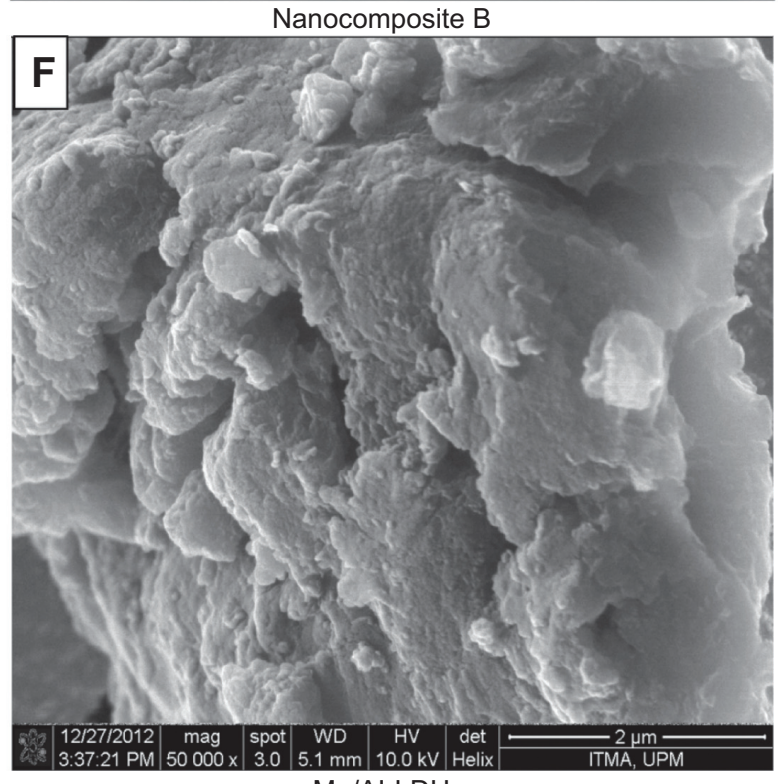

$\mathrm{Mg} / \mathrm{Al}-\mathrm{LDHs}$

Figure 7 Field emission scanning electron microscope micrographs.

Notes: Field emission scanning electron microscope micrographs of the nanocomposite $\mathbf{A}(\mathbf{A}$ and $\mathbf{B})$, nanocomposite $\mathbf{B}(\mathbf{C}$ and $\mathbf{D})$ and $\mathrm{Mg} / \mathrm{Al}-\mathrm{LDH}$ (E and $\mathbf{F})$.

Abbreviation: LDHs, layered double hydroxides. 


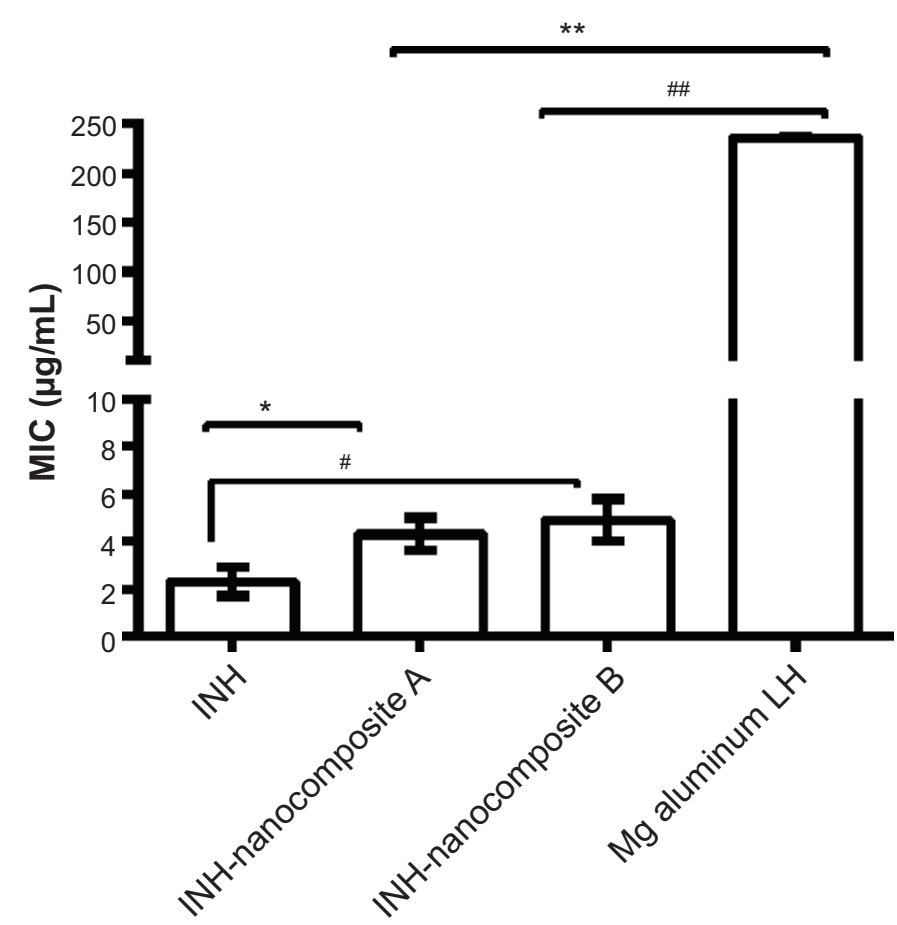

Figure 8 Minimum inhibitory concentrations $(\mu \mathrm{g} / \mathrm{mL}$ ) of isoniazid (INH) nanocomposites compared to INH alone against Mycobacterium tuberculosis.

Notes: Minimum inhibitory concentrations (MIC) of INH nanocomposites compared to INH alone against Mycobacterium tuberculosis as determined by use of a Mycobacteria growth indicator tube with BACTEC MGIT 960 growth supplement for drug susceptibility testing and measured by the MGIT 960 instrument (Becton Dickinson Diagnostic Systems, Sparks, MD, USA). Results were analyzed using Student's $t$-test (unpaired, two-tailed) INH-nanocomposite A against INH, $P=0.021$, *P $<0.05$; INH-nanocomposite $A$ against Mg AL LDH, $P<0.000 \mathrm{I}$, ${ }^{*} * P<0.000 \mathrm{I}$; INH-nanocomposite $B$ against INH, $=0.019,{ }^{\# P}<0.05$; INH-nanocomposite $B$ against $M g A L L D H, P=0.000 I$, \# $P<0.000$ I.

Abbreviation: LDH, layered double hydroxide.

\section{A}

INH-nanocomposite $1 \mathrm{mg}$

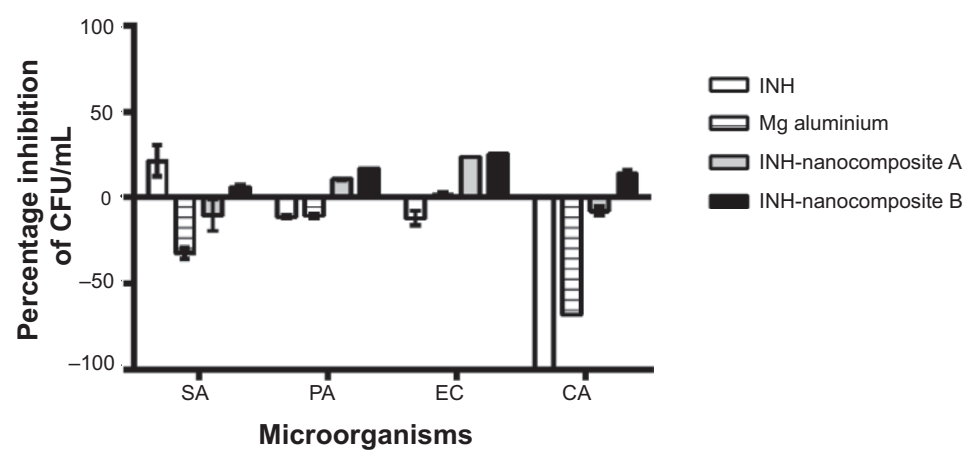

B

INH-nanocomposite $2 \mathrm{mg}$

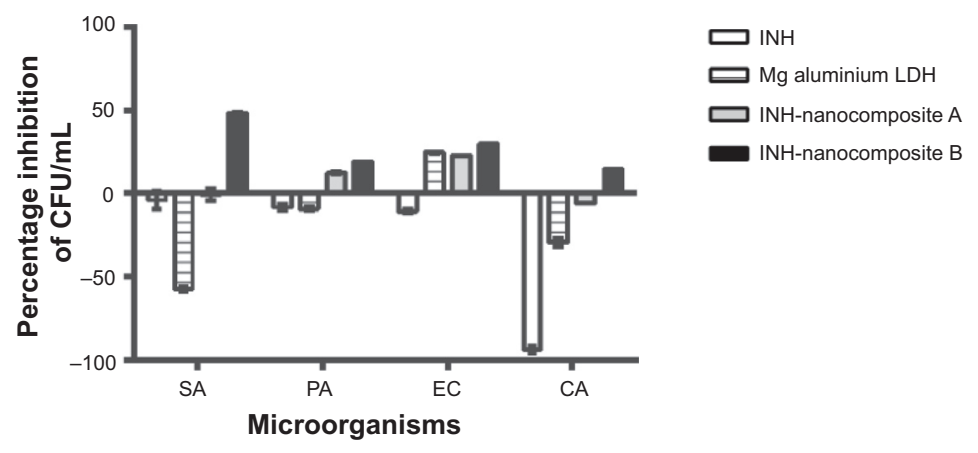

Figure 9 Effect of isoniazid $(\mathrm{INH})$ nanocomposites on the inhibition of microbial growth using plate colony counting method at two concentrations, I mg (A) and 2 mg (B). Notes: All experiments were carried out in triplicate and results are presented as mean \pm SD.

Abbreviations: CFU, colony-forming units; SA, Staphylococcus aureus; PA, Pseudomonas aeruginosa; EC, Escherichia coli; CA, Candida albicans; LDH, layered double hydroxide. 
A

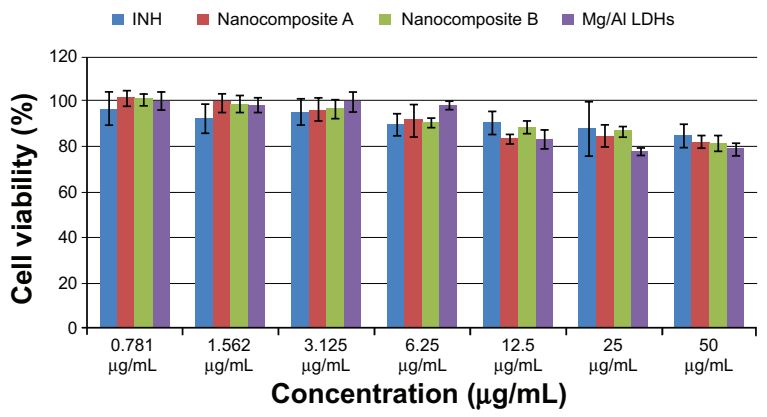

Human normal lung cells MRC-5
24 hours

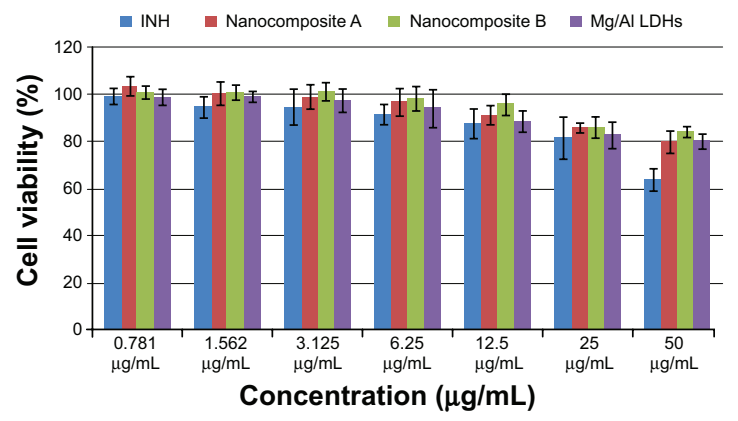

Mouse fibroblast cells-3T3

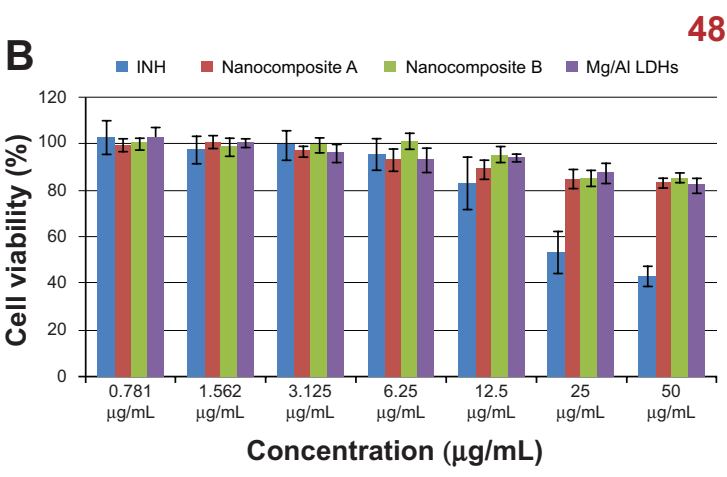

Human normal lung cell MRC-5

48 hours

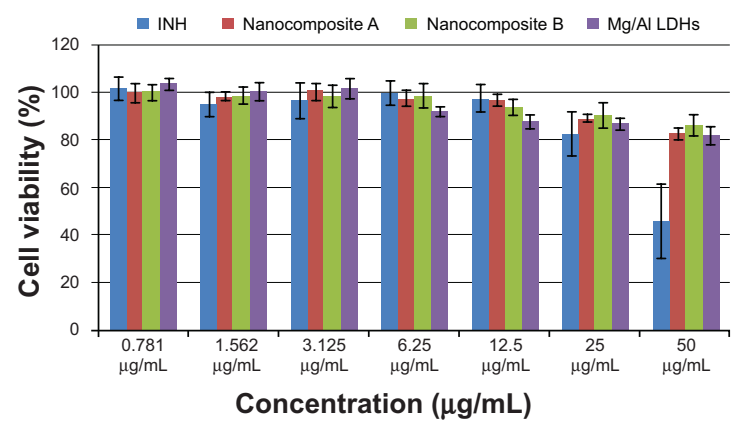

Mouse fibroblast cells-3T3

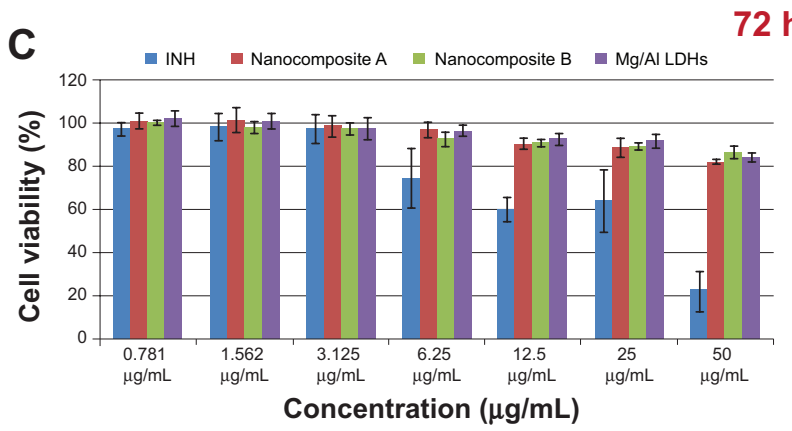

Human normal lung cells MRC-5

72 hours

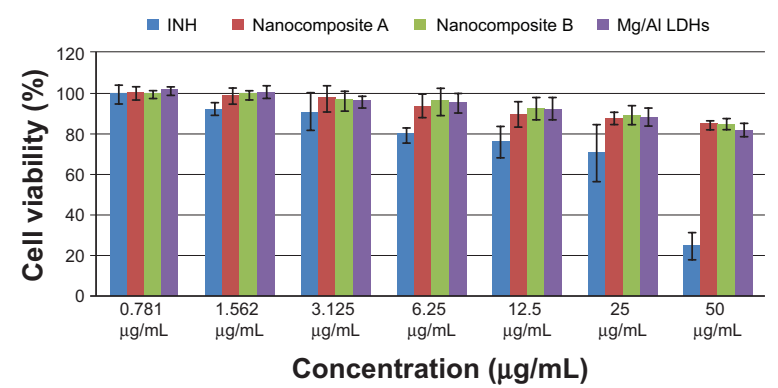

Mouse fibroblast cells-3T3

Figure 10 Viability of human normal lung cells and 3T3 fibroblast cells against free isoniazid (INH) INH-Mg/Al layered double hydroxides (LDHs) nanocomposites and $\mathrm{Mg} / \mathrm{Al}$ LDHs.

Note: (A-C) represents the incubation period of 24 hours, 48 hours and 72 hours respectively.

\section{Conclusion}

This study reported the development of an anti-TB nanodelivery formulation by intercalating the anti-TB drug isoniazid into $\mathrm{Mg} / \mathrm{Al} \mathrm{LDH}$. The release of isoniazid from the formulation was found to be sustained in phosphate buffer solutions at $\mathrm{pH} 7.4$ and 4.8, which followed a pseudo second-order model. The efficacy of INH was found to be $5 \times$ higher in LDH nanocomposite formulations compared to free INH against MTB, and was also found to be active against gram-positive and gram-negative bacteria as well as Candida albicans. The nanodelivery formulation was found to be $3 \times$ more biocompatible compared to the free drug isoniazid. In vitro studies of isoniazid nanodelivery formulation are highly encouraging for further in vivo investigations. It was concluded that the nanocomposites formulation of isoniazid with layered double hydroxides can be very effective against TB. Thus, the present research effort is a step towards developing patient friendly antituberculosis agents of improved antibacterial activity.

\section{Acknowledgments}

Funding for this research was provided by the Higher Education Commission of Malaysia under the Commonwealth Scholarship and Fellowship Plan (Ref: KPT.B.600-6/3, 
Vol 68), for Bullo Saifullah, and the Ministry of Science, Technology and Innovation of Malaysia under the Fundamental Research Grant Scheme FRGS/2/2013/SG06/ UPM/01/1 with vot \#5524467. The authors would like to thank Northeastern University in Boston, MA, USA for funding the experiments.

\section{Disclosure}

The authors have no conflicts of interest to disclose.

\section{References}

1. Sharma SK, Mohan A. Extrapulmonary tuberculosis. Indian JMed Res. 2004;120(4):316-353.

2. Sumartojo E. When tuberculosis treatment fails. A social behavioral account of patient adherence. Am Rev RespirDis. 1993;147(5): 1311-1320.

3. World Health Organization. Global tuberculosis report 2013. WHO Press, World Health Organization, 20 Avenue Appia, 1211 Geneva 27, Switzerland. 2013. http://www.who.int/tb/publications/global_report/ en/. Accessed August 12, 2014.

4. Saifullah B, Hussein MZ, Hussein Al-Ali SH. Controlled-release approaches towards the chemotherapy of tuberculosis. In J nanomedicine. 2012;7:5451-5463.

5. UNAIDS WHOGTPa. Policy statement on preventive therapy against tuberculosis in people living with HIV. 1998. http://whqlibdoc.who.int/ hq/1998/WHO_TB_98.255.pdf. Accessed August 12, 2014.

6. Ramappa V, Aithal GP. Hepatotoxicity related to anti-tuberculosis drugs: mechanisms and management. JCEH. 2013;3(1):37-49.

7. Vidrio H, Medina M, Fernández G, Lorenzana-Jiménez M, Campos AE. Enhancement of hydralazine hypotension by low doses of isoniazid: Possible role of semicarbazide-sensitive amine oxidase inhibition. Gen Pharmacol-vasc S. 2000;35(4):195-204.

8. Schaberg TKR, Lode H. Risk factors for side-effects of isoniazid, rifampin and pyrazinamide in patients hospitalized for pulmonary tuberculosis. Eur Respir J. 1996;9:2026-2030.

9. Tafazoli S, Mashregi M, O’Brien PJ. Role of hydrazine in isoniazidinduced hepatotoxicity in a hepatocyte inflammation model. TAAP. 2008;229(1):94-101.

10. van Hest R, Baars H, Kik S, et al. Hepatotoxicity of rifampin-pyrazinamide and isoniazid preventive therapy and tuberculosis treatment. IDSA. 2004;39(4):488-496.

11. Clemens DL, Lee BY, Xue M, et al. Targeted intracellular delivery of antituberculosis drugs to Mycobacterium tuberculosis-infected macrophages via functionalized mesoporous silica nanoparticles. $A A C$. 2012;56(5):2535-2545.

12. Foradada M, Pujol MD, Bermudez J, Estelrich J. Chemical degradation of liposomes by serum components detected by NMR. Chem Phys Lipids. 2000;104(2):133-148.

13. Marques AP, Reis RL, Hunt JA. Cytokine secretion from mononuclear cells cultured in vitro with starch-based polymers and poly-L-lactide. J Biomed Mater Res A. 2004;71(3):419-429.

14. Lam KH, Schakenraad JM, Esselbrugge H, Feijen J, Nieuwenhuis P. The effect of phagocytosis of poly(L-lactic acid) fragments on cellular morphology and viability. J Biomed Mater Res A. 1993; 27(12):1569-1577.

15. Wang Q, O'Hare D. Recent advances in the synthesis and application of layered double hydroxide (LDH) nanosheets. Chem rev J. 2012; 112(7):4124-4155.

16. Rives V. Applied Clay Science. In: Layered double hydroxides: present and future. Nova Science Publishers, Inc., New York, 2001; 22(1-2):75-76.

17. Duan XE, David G, editors,. Layered Double Hydroxides; Series: Structure and Bonding. Vol 119. Springer 2006.
18. Newman SP, Jones W. Synthesis, characterization and applications of layered double hydroxides containing organic guests. New J Chem. 1998;22(2):105-115.

19. Cavani F, Trifirò F, Vaccari A. Hydrotalcite-type anionic clays: Preparation, properties and applications. Catalysis Today. 1991;11(2): 173-301.

20. Shi L, Li D, Wang J, Li S, Evans DG, Duan X. Synthesis, flame-retardant and smoke-suppressant properties of a borate-intercalated layered double hydroxide. Clay Clay Miner. 2005;53(3):294-300.

21. Yu J, Chung H-E, Choi S-J. Acute oral toxicity and kinetic behaviors of inorganic layered nanoparticles. J Nanomater. 2013;2013:8.

22. Barahuie F, Hussein MZ, Hussein Al-Ali SH, Arulselvan P, Fakurazi S, Zainal Z. Preparation and controlled-release studies of a protocatechuic acid-magnesium/aluminum-layered double hydroxide nanocomposite. Int J Nanomedcine. 2013;8:1975-1987.

23. Kura AU, Hussein Al-Ali SH, Hussein MZ, Fakurazi S, Arulselvan P. Development of a controlled-release anti-parkinsonian nanodelivery system using levodopa as the active agent. Int J Nanomedcine. 2013;8:1103-1110.

24. Hussein Al-Ali SH, Al-Qubaisi M, Hussein MZ, Ismail M, Zainal Z, Hakim MN. In vitro inhibition of histamine release behavior of cetirizine intercalated into $\mathrm{Zn} / \mathrm{Al}$ - and $\mathrm{Mg} / \mathrm{Al}$-layered double hydroxides. Int $\mathrm{J}$ Mol Sci. 2012;13(5):5899-5916.

25. Kong X, Shi S, Han J, Zhu F, Wei M, Duan X. Preparation of glycy1-tyrosine intercalated layered double hydroxide film and its in vitro release behavior. J Chem Eng. 2010;157(2-3):598-604.

26. Zhang H, Ouyang D, Murthy V, Wong Y, Xu Z, Smith SC. Hydrotalcite intercalated siRNA: computational characterization of the interlayer environment. Pharmaceutics. 2012;4(2):296-313.

27. Mohsin SM, Hussein MZ, Sarijo SH, Fakurazi S, Arulselvan P, Hin TY. Synthesis of (cinnamate-zinc layered hydroxide) intercalation compound for sunscreen application. Chem Cent J. 2013;7(1):26.

28. Wang J, Zhu R, Gao B, et al. The enhanced immune response of hepatitis $\mathrm{B}$ virus DNA vaccine using $\mathrm{SiO}_{2}-\mathrm{LDH}$ nanoparticles as an adjuvant. Biomaterials. 2014;35(1):466-478.

29. Oh JM, Choi SJ, Lee GE, Kim JE, Choy JH. Inorganic metal hydroxide nanoparticles for targeted cellular uptake through clathrin-mediated endocytosis. Chem Asian J. 2009;4(1):67-73.

30. Hussein Al Ali SH, Al-Qubaisi M, Hussein MZ, Ismail M, Zainal $\mathrm{Z}$, Hakim MN. Comparative study of $\mathrm{Mg} / \mathrm{Al}$ - and $\mathrm{Zn} / \mathrm{Al}$-layered double hydroxide-perindopril erbumine nanocomposites for inhibition of angiotensin-converting enzyme. Int J Nanomedicine. 2012;7: 4251-4262.

31. Walters SB, Hanna BA. Testing of susceptibility of Mycobacterium tuberculosis to isoniazid and rifampin by mycobacterium growth indicator tube method. JCM. 1996;34(6):1565-1567.

32. Palaci M, Ueki SY, Sato DN, et al. Evaluation of mycobacteria growth indicator tube for recovery and drug susceptibility testing of Mycobacterium tuberculosis isolates from respiratory specimens. JCM. 1996;34(3):762-764.

33. Usman MS, El Zowalaty ME, Shameli K, Zainuddin N, Salama M, Ibrahim NA. Synthesis, characterization, and antimicrobial properties of copper nanoparticles. Int J Nanomedicine. 2013;8:4467.

34. Saifullah B, Hussein MZ, Hussein-Al-Ali SH, Arulselvan P, Fakurazi S Sustained release formulation of an anti-tuberculosis drug based on para-amino salicylic acid-zinc layered hydroxide nanocomposite. Chem Cent J. 2013;7(1):72.

35. Saifullah B, Hussein MZ, Hussein-Al-Ali SH, Arulselvan P, Fakurazi S. Antituberculosis nanodelivery system with controlled-release properties based on para-amino salicylate-zinc aluminum-layered double-hydroxide nanocomposites. Drug Des Devel Ther. 2013;7:1365-1375.

36. Chih-Chun Wen, Hui-Ming Chen, Swey-Shen Chen, et al. Specific microtubule-depolymerizing agents augment efficacy of dendritic cellbased cancer vaccines. JBSR. 2011;18:44.

37. Parida KM, Mohapatra L. Carbonate intercalated Zn/Fe layered double hydroxide: A novel photocatalyst for the enhanced photo degradation of azo dyes. Chem Eng J. 2012;179(0):131-139. 
38. Akyuz S, Akyuz T. FT-IR and FT-Raman spectroscopic studies of adsorption of isoniazid by montmorillonite and saponite. Vibrational Spectroscopy. 2008;48(2):229-232.

39. Gunasekaran S, Sailatha E, Seshadri S, Kumaresan S. FTIR, FT Raman spectra and molecular structural confirmation of isoniazid. IJPAP. 2009; 47(01):12-18.

40. Dirtu D, Odochian L, Pui A, Humelnicu I. Thermal decomposition of ammonia. $\mathrm{N}_{2} \mathrm{H}_{4}$-an intermediate reaction product. Cen Eur J Chem. 2006;4(4):666-673.
41. Kong X, Jin L, Wei M, Duan X. Antioxidant drugs intercalated into layered double hydroxide: Structure and in vitro release. Applied Clay Science. 2010;49(3):324-329.

42. Ho YS, Ofomaja AE. Pseudo-second-order model for lead ion sorption from aqueous solutions onto palm kernel fiber. J Hazd Mater. 2006;129(1-3):137-142.

43. Chen XT, Mi F, Zhang H, Zhang HQ. Facile synthesis of a novel magnetic core-shell hierarchical composite submicrospheres $\mathrm{Fe}_{3} \mathrm{O}_{4}$ CuNiAl-LDH under ambient conditions. Mater Lett. 2012;69:48-51.

\section{Publish your work in this journal}

The International Journal of Nanomedicine is an international, peerreviewed journal focusing on the application of nanotechnology in diagnostics, therapeutics, and drug delivery systems throughout the biomedical field. This journal is indexed on PubMed Central, MedLine, CAS, SciSearch ${ }^{\circledR}$, Current Contents ${ }^{\circledR} /$ Clinical Medicine,
Journal Citation Reports/Science Edition, EMBase, Scopus and the Elsevier Bibliographic databases. The manuscript management system is completely online and includes a very quick and fair peer-review system, which is all easy to use. Visit http://www.dovepress.com/ testimonials.php to read real quotes from published authors. 